\title{
Technology Innovation - Electronic Game in the Brazilian Higher Education
}

\author{
Claudia Marques Araujo', Ilda Maria de Paiva Almeida Spritzer², Cristina Gomes de Souza ${ }^{3}$
}

\begin{abstract}
The Information and Communication Technologies provide a world of discoveries, relations and leanings, presenting possibilities that can help the teaching and learning process to adapt to the new social dynamics introduced by its use. The electronic games (video games), in particular, for its playful nature and because they are familiar to the young people, may provide a great assistant in this adaptation. The research presented here takes a theoretical framework based on Brazilian and international reference authors, to through action research, implement video games about financial mathematics, in a discipline of a higher education course of a public university in Brazil. The results confirm that the use of electronic games is well received by the students, showing that they perceived them as a motivating practice and as an introductory agent of a new process of teaching and learning for higher education.
\end{abstract}

Keywords: video games; educational technology; higher education; learning and teaching process.

\footnotetext{
'Diretoria de Pesquisa de Pós-Graduação Programa de Pós-Graduação em Tecnologia, Centro Federal de Educação Tecnológica Celso Suckow da Fonseca ,Av. Maracanã, 229 - Bloco E - $5^{\circ}$ andar, RJ, Brazil., 2027I-I I0, +55 (2I) 2566-3I 79, claudiarau@terra.com.br ${ }^{2}$ Diretoria de Pesquisa de Pós-Graduação Programa de Pós-Graduação em Tecnologia Centro Federal de Educação Tecnológica Celso Suckow da Fonseca ,Av. Maracanã, 229 - Bloco E - 5ªndar, RJ, Brazil., 2027I-I I0, +55 (2I) 2566-3 I79, spritzer@cefet-rj.br ${ }^{3}$ Diretoria de Pesquisa de Pós-Graduação Programa de Pós-Graduação em Tecnologia, Centro Federal de Educação Tecnológica Celso Suckow da Fonseca ,Av. Maracanã, 229 - Bloco E - $5^{\circ}$ andar, RJ, Brazil., 2027I-1 I0, +55 (21) 2566-3179, cgsouza@cefet-rj.br
} 


\section{Introduction}

A new world of discovery and learning is made available by the Information and Communication Technologies. What in the past could only be imagined, can frequently be viewed in computer screens, making the learning process more easy, but more sophisticated. The communication with people from different places, cultures and social circles, is also a new factor that interferes and contributes to a new knowledge horizon. Social networks, online education, connected cities for a better use of the planet resources are only a few of the changes that started to appear in today's world, creating new social dynamics and a new social space.

The students' contact with the Information and Communication Technologies, since their childhood and the available technology, that can be used to the higher education are important factors that need to be taken in consideration and evaluated to reach the modernization and better adaptation of the teaching process to the new social dynamics.

The actual teaching process has been structured on the same way for many years, but only added by the eventual use of the computers, what many times is perceived as tedious by the students, when compared with the possibilities and technologies used and available for them. Some authors highlight that the students that were born in this actual environment, surrounded by technology, have different behavioral characteristics and learning styles, because of its contact with the technology since their childhood. Many of these characteristics and learning styles are explored by the electronic games, that are normally part of the students reality and such games have learning principles that are in sync with this new social space.

Children, young people and adults are capable of a profound dedication to the electronic games, spending hours of their days to complete a phase or finish a game, what shows that the task is not easy or simple. It requires dedication, attention, patience and great interest in win, making the activity fun, but many times difficult. But besides its difficulty level, the games still attract players. Use the games to increase the interest and dedication of the students in the learning and teaching process, making it more natural and adapted to the new social space, may bring a great enhancement and help to transform this process. The electronic games classification used here includes computer games, digital games, cellular games, video games and other type of games that are executed in electronic equipment.

These possibilities and the changes in the social and cultural dynamics motivated the development of a research work, objecting identify and test practices that can make the teaching and learning process of the higher education disciplines more interesting and adapted to this new social space, through the development and implementation of the electronic games. Bibliographic material of international and Brazilian authors was analyzed and this analyze built the research theoretical framework, being the following some of the authors visited: João Mattar (2009), Lynn Alves (2004), Marc Prensky (2007), Don Tapscott (2010), Javier Echeverria (2004), Pierre Lévy (1999) and James Paul Gee (2007). Tactics that allow the professor to include games in their classroom routines were identified and adopted in a higher education course, and the text that follows will present in details part of this research.

The new social space and the teaching and learning process According to Echeverría (2004), a technology philosopher, there are three types of environments, called by the author in his original language "entornos", in human evolution and its relationship with society. The first one, called by the author $\mathrm{EI}$, is the natural environment where the human beings learned to adapt to it and to adapt the environment to their needs. The second one, E2, is a cultural and social environment. It is formed by the people and the cities where the men live and it does not suppress El, but it changes it. The third one, E3, is a new social time and space. It is basically artificial and it depends in great part of the technological innovations. E3 has special importance for education because it allows the use of computer network, called telematics networks by the author, on its behalf. Man need to build new skills and knowledge to operate in E3 and the schools and universities need to adapt to this new environment, what means to create a new system of educational centers, with new tools and methods. In the perspective of the authors of this article, the three environment present different types of technologies, but the difference from the $E 3$ technologies to the EI and E2 ones is the artificiality or virtual character that $\mathrm{E} 3$ generates.

Lévy (1999) talks about the appearance of a universal new, expressed by the Cyberculture, which is different from the other cultural forms that exist before it. The author defines Cyberculture as:

"The set of technologies (material and intellectual), practices, attitudes, modes of thought, and values that developed along with the growth of cyberspace".

Still by this author, Cyberspace, also called network is:

"The communication space made accessible through the global interconnection of computers and computer memories." (Lévy, 1999)

By Echeverría (2004) EI and E2 are characterized by having the nature as object to be explored. In E3 this changes and 
knowledge becomes the object to be explored and because of that it makes sense to talk about knowledge society.

The young people of the actuality are inserted in the cyberspace and cyberculture. The use of the Information and Communication technologies is part of their lives, but when dealing with the teaching and learning context, for many times they are transported to a reality where the new practices, technologies and attitudes are not usual, making them do not recognize it, refute or consider tedious and of low value. The environment where the young people live today offers interesting and natural opportunities for them, but such opportunities are not leveraged by the schools and teaching institutions, and the way of teaching still does not largely benefits from the technological resources or use them as motivation factor.

One of the most popular uses of the new technologies in the teaching and learning process today is distance learning. A continuous growth in the offer of courses and students that look for this type of education proves its importance. According to the "Censo da Educação Superior 2010" 2010 Higher Education Census made by Inep, a Brazilian research public institution, 930 courses of distance learning are offered by the higher education institutions in 2010,86 more than the previous year. In 2002 there were only 46 distance learning courses. This number grew up to 930 in 2010. According to Matias-Pereira (2008) distance learning is an important resource to promote inclusive education, helping to address geographical distances, especially in a country of the size of Brazil. The author also highlights the importance to guide govern incentives and research development to new distance learning practices to help to improve the relationship with the face to face education.

Although distance learning is an initial use of the new technologies in the education process, what happens, many times, in this way of teaching it is the transposition of the existent content for this type of offerings, using the same principles of the face to face education, not exploring the E3 and the Information and Communication technology resources. Echeverría (2004) says that the pure and simple conversion of the materials to this new environment is a mistake. Prensky (2007) points out that the "tell-test" model, where the professor "tells" content to the students and test them on it, many times is transported to distance learning. Mattar (2009) highlights that the content is taught using technology, but in the same way that is taught face to face, but prettier as multimedia resources are used. For this author, such offers are perceived as serious ones because they have evaluation modules to verify the learning. Santos (2005) shows the difference between the traditional distance learning and online education. For this author, the first one has as main characteristic the self-learning, being the learning process mediated by the material. In the online education, besides learning with the material, the student also learns with the other individuals involved, such as professors, tutors and other students, through synchronous and asynchronous communication.

Lévy (1999) highlights that the students are less and less willing to follow rigid courses and courses that are not associated in some way to their life projects and specialization needs. It is necessary to think different and have a strategy for the future generations. Prensky (2007) mentions that what is not seen yet in the distance learning is fun, and that in the future, what is not fun will be rejected by the students. Cecchettini (20II) also highlights that the actual young people need continuous stimuli and many look for pleasure, not easily tolerating the lack of it, what make the motivation one of the main facilitators on the relationship of the professorstudent in the teaching and learning process.

Frequently young people spend many hours in front of the computers or playing games, but they are not willing to spend the same energy and time on their educational tasks. Use electronic games to gain a greater interest and dedication of the students is a possibility to enhance the teaching and learning process. To play is not an exclusive activity of the small children. Children in school age and adults also play. According to Vygotsky (1966) the work is an activity based in rules, what is similar to some type of games. In the case of children Vygotsky (1966) says that play is source of development. Still by this author the relationship playdevelopment may be compared to the relationship learningdevelopment, but play allows acting in the imagination area allowing changes and the building of imaginary situations.

\section{The electronic games in the teaching and learning process}

According to Byington (20II) the young people are fascinated by the video games, because they present emotion in conjunction with the rationality of the computer, providing the knowledge experience. Still according to this author, when learning from video games, the students have the experience of the mind in conjunction with the body and such experience is quick and vital.

Prensky (2007) says that there are three reasons for him to believe that what he calls "Digital Game-Based Learning" will be the way that people will learn. The reasons are: Digital Game-Based Learning meets the learners' needs and learning styles of the actual and future generations; it is "motivating because it is fun"; and is versatile and adjustable to different subjects, information or skills to be learned and it is very effective when used correctly. 
The inclusion of the games in the teaching and learning process may help the students to perform a role that is more active on it, feeling more adapted to this type of dynamic. Its integration in the curriculum is a great challenge and normally the educational games are not as fun as the traditional ones, because constantly they are only different ways to present the content with images and some type of action, according to Mattar (2009).

According to Gee (2007), good video games have good learning principles and they allow the learning to be arduous and challenging. The author also points that a dilemma that already endures for a long time in education is the need to provide a great amount of information to allow the students to learn efficiently, but also the need to be immersed on context and practice. Still by the author, the developers of video games don't have a choice and they need to solve this dilemma in order to make the people to learn and play their products.

Alves (2004) highlights that video games are proving a new learning space, allowing:

"the learning, the communication, the establishment of new links, relationships, development of motor, linguistics and social skills, enhancing the construction of new perspectives, meanings and meaningful to the society in which they are inserted" (free translation of Alves, 2004).

The professors may easily place their materials in question and answer games that are one of the five categories of electronic games that may be used in the teaching and learning process, identified by Prensky (2007). The categories identified by the author are: simple question-and-answer games, off-the-shelf games, e-mail games, games templates and custom games.

Still by Prensky (2007), to start to use the learning based in electronic games, it is enough to build a simple questionand-answer game, using simple HTML programming or existing templates available in the Web. Off-the shelf games are another example of an easy way to get started, but it is not always the cheapest way. Another simple way to get started is the e-mail games that do not require sophisticated technology, but many times are enough to achieve the objective targeted.The use of games templates is another example of how to develop a game in a simple way. The option of custom games is normally the one that requires a large amount of investment. If the professors have access to the correct tools, they probably will be able to build good and interesting games, even if they use the simplest way of digital games (Prensky, 2007).
Professors are already using and testing electronic games in their teaching routines.A research conducted in two schools in Sweden in $\mathbf{2 0 0 9}$ on the use of a math game, to check if the game supported the mathematical principles related to the conceptual understanding of basic arithmetic and in particular the numbering system of positional base 10. Lindstrôm, Gulz et al (20II) concluded that the game worked for the learning of spatial relationships to more complex abstract mathematical representations and to guide students' attention to the development and understanding of the subject. Another example is the work of Akkerman, Admiraal and Huizenga (2009) used a history game called Frequentie 1550 , that allowed students to actively participate in the history of Amsterdam walking around town, completing quests and receiving messages. The authors' analysis shows that the participation type of Storification presented in the game is considered more intense than the others, since the student is living the history, but on the other hand, while they were trying to find their way around town and complete quests, they became distracted and lost focus on the narrative and structure of the game. This raises the question of how to use the narrative in the game in order to keep students involved, but not distract them from the main points associated with it.

The research conducted by Costu, Aydin and Filiz (2009), related to the use of internet browsers games, made many students start to think that mathematics would be easier and less annoying, making the abstract topics more concrete. A study with twenty students in Netherlands, that played a strategy game called Lemonade Tycoon, found out that solitary and partnered players had a similar level of engagement related to collaborative game approach (Meij, Albers and Leemkuil, 20II). Other cases like the study of the Demirbilek and Tamer (2010) on the use of computer games by thirteen math teachers, and the one by Giroux and Pasin (20II) which analyzed 100 teams of undergraduate students who played the simulation game HECOpSim and the one by Tao, Cheng and Sun (2009) to understand how students perceive the business simulation game and their intentions to continue to use it are also good examples on the use and research around electronic games.

Through experiments and the studies mentioned before it is possible to see that the inclusion of electronic games in teaching and learning can help modernize the current teaching methods at different levels of education. Include such practices is a challenge, but a need that could make the student more interested in the higher education routine, making the process to be more fun and more adapted to the new culture and social dynamics, allowing the learning to be more committed and active by the students. The work presented here explores how a simple question-and-answer game was developed and applied in a higher education dis-

ISSN: 07 I8-2724. (http://www.jotmi.org)

Journal of Technology Management \& Innovation (c) Universidad Alberto Hurtado, Facultad de Economía y Negocios. 
cipline, as part of a set of actions adopted in a research on electronic games and learning in higher education to obtain the title of Master in Technology from CEFET/RJ by one of the authors.

\section{Method}

The research developed used the action research methodology, as a strategic research methodology as considered by Thiollent (1998). This type of method implies a cycle of planning, action, observation and reflection (Collis and Hussey, 2003), the researcher to perform an active role in the reality of the facts and that the research is articulated taking a theoretical framework (Thiollent, 1998). The importance of the space-time dimension in this type of research is highlighted by Barbier (2007), also pointing that all action research is related to a single problem and caries the hope of a possible change or problem solving.

The research was limited to the students from higher education, being the active research applied in two classes of the Financial Mathematics discipline of the Industrial Administration course of the "Centro Federal de Educação Tecnológica Celso Suckow da Fonseca", a public higher education institution, located in Rio de Janeiro, Brazil in its unit at Maracanã in 20II.The discipline has as its objective to capacitate the students to utilize concepts and practices of financial mathematics, to understand the foundation to calculate the value of money in time and to teach how to utilize ICT to analyze financial information for the decision process, as described in its program.

The initial step of the research cycle involved the observation of the discipline during the semesters. The action plan was created based on the needs identified through the analysis and observation of the discipline during the course. Three activities were identified at the start of work and validated during the design and deployment of them. Although distinct, they formed a complete set of actions to expand the educational institution for $\mathrm{E} 3$, applying computer games and games tactics to make the learning process of the young people more dynamic and interesting, exploring some of the differences of the new social space and the learning principles found in the games. The data collection methods of the results of the actions introduced in the course were the participant observation of the implementation of the electronic games and questionnaires administered after each action. A mix methodology was used for data collection, to allow a greater flexibility when obtaining the information about the deployment of the games. Notes were taken and considered and questionnaires for feedback collection were distributed. The reflection was made by analysis of the observations and the questionnaire responses to see if students perceived the computer games as motivators and agents of an introduc- tory teaching and learning process for disciplines of higher education courses. The details of the implementation of the actions of the research and its results will be presented throughout this text.

\section{The games and the selected discipline}

In order to analyze the potential of the video games in the teaching and learning process and how the students perceive this new dynamics, the proposal of this research was to identify and test tactics that allow the professors to include electronic games in their classroom routines, in disciplines of higher education courses, considering the characteristics of the actual students inserted in the cyberspace.

The discipline chosen was financial mathematics, what is in agreement with Prensky's (2007) view that affirms that a subject is a good candidate to the learning based in games when it is "hard","dry", and technical or need to be repeated constantly to be performed correctly. The traditional classes of the discipline were observed during the two semesters of 201 I. This discipline also had another differential on the same year, with the inclusion of the Moodle, as a Learning Management System, to organize contents, make material available, to publish calendars, grades and messages and to allow the students to post their contributions related to the discipline. This type of use, although still in a very traditional way, was considered an innovation, because the majority of the disciplines do not count with this type of technological support in the institution where the work was developed.

The selection of the electronic game to be developed and specially the selection of the tools to be used to develop the games had as guide principle the need to use simple and easy tactics. The use of simple and easy tactics was considered key for the adoption of the electronic games in the teaching and learning process, as the professors need to learn the new tools in order to create their games. Complex tactics would require more time and dedication from the professors, what would make more difficult to implement this type of activity in the future and it could even demotivate the professors.

Three different activities were developed and implemented in the financial mathematics classes:

- the application of the Portuguese version of the Financial Soccer'. A game created by Visa and available over the web at http://www.financialsoccer.com, addressing basic concepts of finance and financial mathematics.

- the creation of a question-and-answer game, the Financial Mathematics Show

- the creation of a game that would be closer to commercial video games, the Financial Mathematics Great Mission. 
This article will focus on the creation and deployment of the second game, the Financial Mathematics Show.

\section{The creation of the Financial Mathematics Show}

The games were deployed during $20 \mathrm{II}$ and at the beginning of each semester the students were informed about the dynamic of the games and that their participation and good results on them would worth point in their final grade. The first semester's class had thirty five students enrolled, where four have not completed the course and the one from the second semester had fifty two students enrolled, where two have not completed the course. The classes were taught on Wednesdays from 6:20PM to 9:50PM and usually when electronic games would be deployed other academic activities did not occur and the applications of them would take almost all the class time.

The Financial Mathematics Show was planned to be presented at the middle of the semesters, when normally the students have some difficulties with the content. Considering this scenario, the plan was to create a game that could help the students to exercise what they learned, acting as a content review. The question-and-answer games are a good option to reach this objective and a simple way to introduce a game in the teaching process of schools, higher education institutions and corporations. This type of game allows the content to be adapted to the needs of who will play and the emotional involvement on it is very high what normally increases the retention of content, according to Prensky (2007). The author also states that question-andanswer games are not the most sophisticated type of games and are often used to review and reinforcement of content learned, but they are an evolution in traditional lecture format and a simple way for the professors to start using the game based-learning.

The Financial Mathematics Show, presented in Figure I, is a question and answer game, played in teams, developed using Microsoft PowerPoint. The dynamics is initiated by a raffle to define the first team to play. Then each team chooses a category in a panel showing the four available - Simple Interest, Compound Interest, Interest Rates and Annuities - and the value of the question. The teams have two minutes to answer a question and the question once chosen cannot be selected by another team.

Microsoft PowerPoint ${ }^{2}$ was selected for the development of this game, with the objective to use a simple way to create it, using a tool that the professors are already familiar

'Financial Soccer is a registered trademark of Visa.

All rights reserved to Visa.

${ }^{2}$ All rights reserved to Microsoft Corporation. with. The game was developed from an initial template created by Jefferson County School and found on the "PowerPoint Games" area of their site, available at http://jc-schools. net/tutorials/ppt-games/. This standard has been improved, adapted and modified for the needs of the content to be presented. The creation of the game began in March $201 \mathrm{I}$ and the game was first presented in May of the same year. The development was not full-time, and another game was developed in parallel, among other activities during the same period.

Other possibilities of templates and applications were analyzed before the adoption of Microsoft PowerPoint2, such as the use of an internet tool. The application on the SuperTeacherTools, site available at http://www.superteachertools.com/jeopardy/, is a good example of this type of tool, but it was not adopted because lack of support to the Portuguese language at the time of the selection and because it was preferred to use a standard that professors would be more used to.

\section{Show da Matemática Financeira}

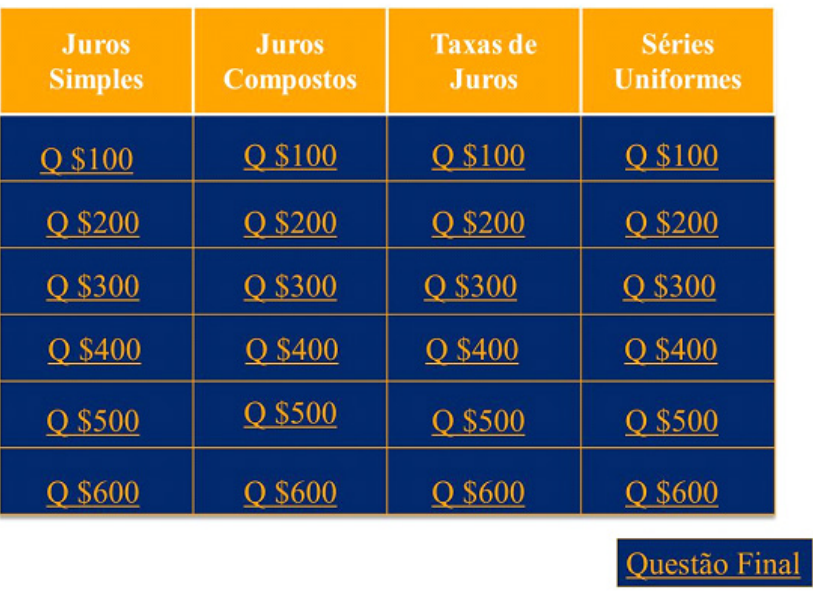

Figure I: Question-and-answer game - Financial Mathematics Show/ Source: Created by Araujo (2012) based on a template created by "Jefferson County School", available on the internet.

In the conception of the authors of this article, it is possible to identify some learning principals found in this electronic game, based on the thirty six learning principles identified by Gee (2007) in his work. The following principles can be identified in the game:

- $\quad$ Psychosocial Moratorium Principle - the electronic games allow the students to take risks, in a controlled environment, without serious consequences. In the case of this game the students tested their knowledge of the content not in an evaluation context and consequently without negative implications.

ISSN: 07 I8-2724. (http://www.jotmi.org) 
- $\quad$ Practice Principle - this principle implies in practice in an environment that is not boring and in which the players agree to spend many hours. The game developed allowed the practice and exercise of the concepts learned in the discipline in a different and fun context.

- $\quad$ Achievement Principle - this principle is associated with the fact that for players of all skill levels there are rewards from the beginning, customized by effort levels, among others. The game mentioned here provided return through questions answered correctly and the questions had different levels of difficulty and different values associated to each level, being the winnings converted in points.

- Multimodal Principal and Cultural Models about Learning Principle - The Multimodal principle emphasizes that learning and thinking are built on various media, not only in words. In the Cultural Models about Learning principle is defended that the learners should think consciously about their cultural models of learning without affecting its identity. The two principles can be associated to the game because the students were exposed to a different way of learning, different from the traditional approaches and using different type of medias.

- $\quad$ Regime of Competence Principle - The video game players are constantly asked to act within the limits of their competencies, as highlighted in this principle. This principle can also be related to the game discussed here, because some of the questions are challenging and they required the players to work on the limit of their competencies.

- $\quad$ Affinity Group Principle - People form affinity groups and not groups based on race, gender, culture and others, according to this principle. Affinity group is defined by Gee (2007) as a group of people who are oriented to a goal or a journey using common social practices. As the game was created to be played in teams, this is another principle that is also presented on it, especially because when the game was played the students already knew each other and were forming their affinities groups in class.

The way these principles were applied in this game, was not under evaluation in the work developed, and possibly some were better implemented than others, because it was an initial approach on using them and because certain principles have not been the focus of which was developed.

The presentation created for the game has a total of 80 pages, music to react to correct or wrong answers and a timer that marks the time to answer the question, all the resources created using Microsoft PowerPoint. Besides the game were also created:
- a document with quick instructions that students received printed on the day of the game

- $\quad$ sheets to list the players of the team and write the bet on the final question

- questionnaire for collecting feedback.

\section{The deployment of the question-and-answer game}

When the Financial Mathematics Show was deployed, it was positioned as a question-and-answer game, such as those played in TV channels worldwide. A traditional program of the USA television, “Jeopardy", was remembered, because an IBM computer has played and won two human players in February $201 \mathrm{I}$.

The class was divided into six teams and the order in which they would play was decided by the players by a raffle before they start the game. The necessary infrastructure for the dynamic is just a computer with sound adapter and speakers and a projector for displaying the computer image. Each team would choose a category from one of the four available and then the value of the question to be answered. The correct answer would add the value of the question to the total of the team and the wrong answer would discount it. Won the game the team that finished with more points. After the game, the students were asked to fill out a questionnaire to collect their "feedback".

Using the methodology of action research, changes were made to the second presentation of the same game, based on observation of the first presentation and reflection on it. Some questions were considered difficult by the participants for the value they had and some too easy, what caused these questions to be moved to higher values and vice versa. The time for answer simple interest questions, was also increased to three minutes, because the resolution for those questions is algebraic and demands more time. Another change implemented, now in the rules of it, was related to the bet on the final question. In the first presentation of the game, the teams were able to bet their accumulated amount until the end of the game in the final question, and the bet was made in written before the question was presented. As some teams had negative totals, this prevented them from making bets, causing some controversy. In the second presentation of the game the final question received a maximum of $\$ 1,000$ (one thousand) and all teams had to answer it and they could bet from $\$ 100$ to $\$ 1,000$, in writing, before the question would be presented.

In the second presentation of the game six questions were made available in a paper document, in case a student did not wish to participate and would prefer to answer the questions on paper. The value assigned to each question in the printed version was the same one of the game. Al-

ISSN: 07 I8-2724. (http://www.jotmi.org)

Journal of Technology Management \& Innovation (c) Universidad Alberto Hurtado, Facultad de Economía y Negocios. 
though no students requested the use of the material, this approach was taken using Prensky's (2007) guidance where for non-players, who do not like to play, it should be offered an alternative, what was actually missed by a student in a previous presentation of another game. Another point to be considered is gender difference related to game patterns. This difference seems to also impact the use of internet, as acknowledged in the research conducted by Galvis (20I0), in selected Latin America countries. A similar study in Spain, also concluded that related to frequency, male use of internet is around 10\% higher than woman use (Gargallo-Castel, Esteban-Salvador and Pérez-Sanz, 2010), but it also says that the difference is reducing, what means that there will be close to the same amount of women and men online in the future. The same trend is seen in game playing and Prensky (2007) affirms that initially men/boys would play much more, but this scenario is changing and in the last years more and more females are playing. This tendency can be confirmed in the answers received via the questioner, where the majority of both genders have selected that they play in average five hours per week.
On the two occasions the game was very fun and the students were already counting and waiting for the opportunity to participate in the upcoming activities. Play the game generated great excitement in the room and using the responses from the questionnaire it is possible to confirm this observation, since more than $96 \%$ of students from both semesters responded positively to the question "Use of classroom space to play the Financial Mathematics Show was interesting and fun", based on Likert scale. This type of scale was used because it allows the students to express degree of agreement or not with the statements presented in the questionnaire. Figure 2 shows the distribution of responses in both semesters.

Students found the Financial Mathematics Show more interesting than the first game, which can be confirmed by the response to the question "What game was more interesting?" where $78 \%$ of students chose this game, among the two presented until then. This preference may have occurred because the game was presented after the results of the first evaluation, where several students did not obtain good results and this game provides a good way to exercise the content learned.

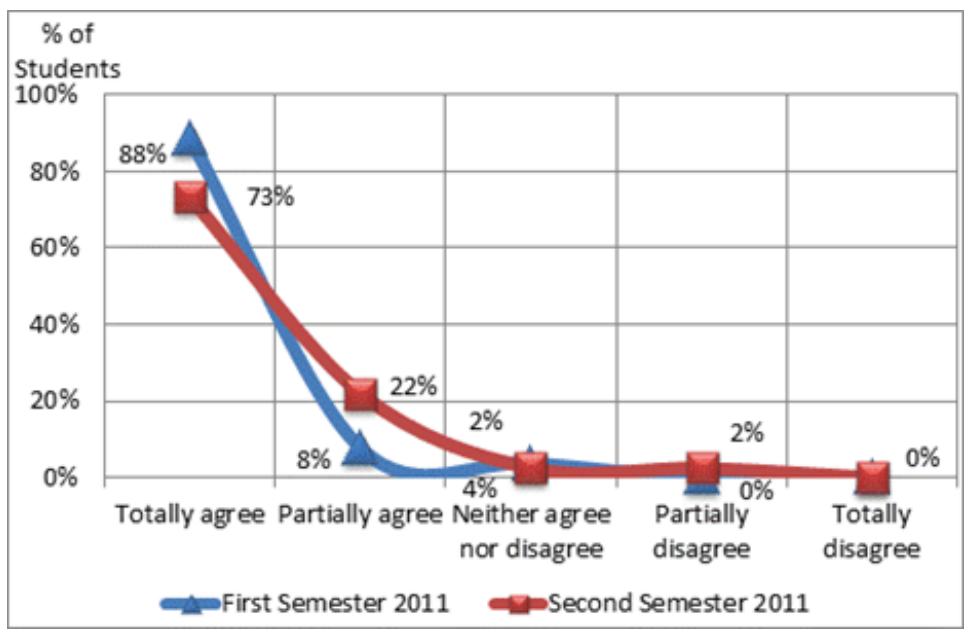

Figure 2: Use of classroom space to play the Financial Mathematics Show was interesting and fun / Source: Created by Araujo (2012) using the answers from the feedback questionnaire presented after the game

Prensky (2007) highlights the importance of two major dimensions related to digital games-based learning. These dimensions are the commitment and learning. By this author the game-based learning only happens when commitment and learning are high and are balanced. It is necessary to select a game style that seeks commitment and a learning style that teaches what is needed. The main reason for preferring the Financial Mathematics Show appointed by the students was "The game is more related to the content learned", as shown in Table I. In this case external factors, the low degrees, led to a major commitment of students to the game and as the content of the game was very didactical and aimed at addressing financial mathematics questions, one can conclude that learning was also high. 


\begin{tabular}{|l|c|}
\hline The game is more related to the content learned. & $37 \%$ \\
\hline Answering the questions requires knowledge of the content. & $25 \%$ \\
\hline The game serves as reinforcement of the content learned. & $25 \%$ \\
\hline The dispute between the teams was the most exciting of Financial Mathematics Show. & $14 \%$ \\
\hline
\end{tabular}

Table I: Reasons for choosing the Financial Mathematics Show as the preferred game/ Source: Created by Araujo (20I2) using the answers from the feedback questionnaire presented after the game

This trend was maintained until the end of the introduction of all games and $49 \%$ of the students preferred this game among the three presented. This preference was strongly influenced by the responses of the class from the second half of the year, as shown in Figure 3, since $55 \%$ of the students chose this game compared to $40 \%$ in the first half. In the first half $44 \%$ of students chose the Financial Mathematics Great Mission, a Role Playing Game also created for the discipline, as the best game, against only $21 \%$ in the second half.

The reasons for this class to have chosen this game may be related to the amount of holidays in the day that the class was held in the second half, which greatly limited the opportunities to practice the content learned in classroom with the support of the professor. Therefore, especially in the second semester, the students were seeking opportunities for this type of reinforcement, combined with the fact that the grades of the first evaluation were in many cases below the average. As the Financial Mathematics Show presents a more didactical and traditional approach in the way ques- tions are offered, possibly generated a perception of review and opportunity to do more exercises, meeting a need of the students and exploring the practice learning principle (Gee, 2007) which is very strong in the game.

Some comments shared by the students in the questionnaire show the support to the initiative and how it was well received by them. One respondent highlighted the fact the game was interesting, helped to fix the content learned and to kill doubts in an exciting way. In the words of another respondent: "The Interaction is excellent.We learned playing!". Other comments encouraged and solicited the adoption of the games in other disciplines and by other professors. Some students highlighted the fact of the game to encourage the study as the following one: "This game makes the student put in practice the content learned. It made us absorb the content and search the knowledge in order to win the competition."

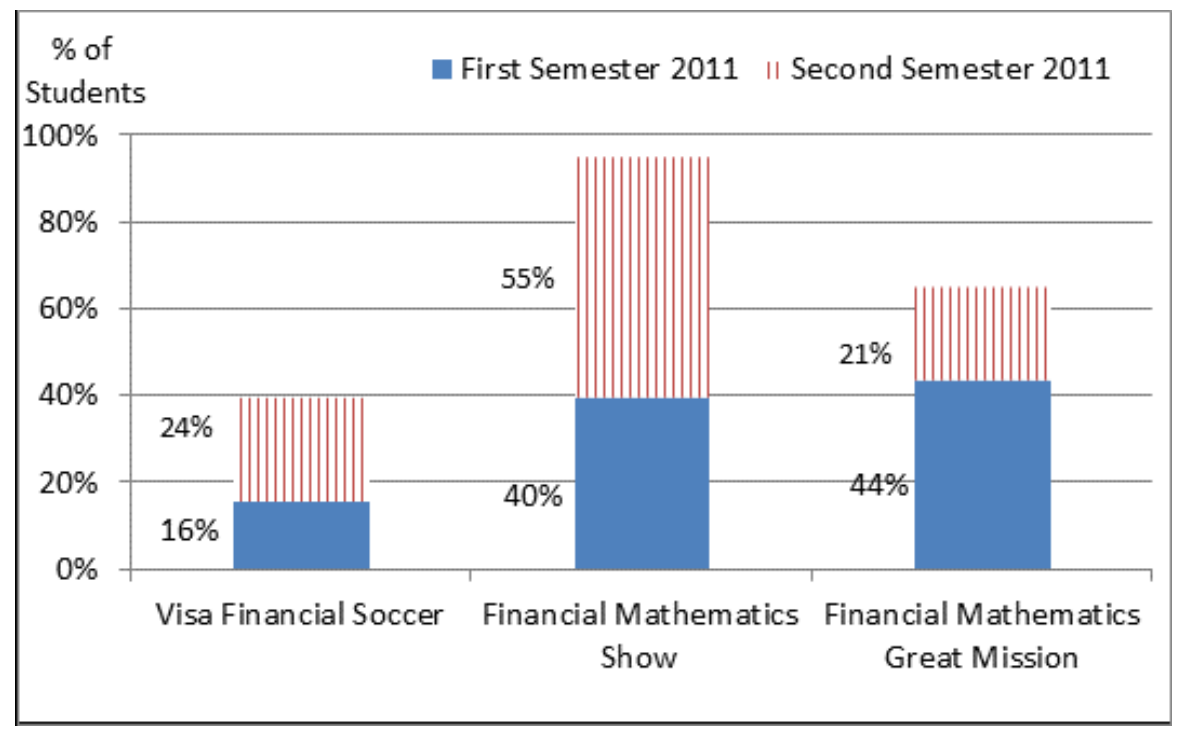

Figure 3:What game was more interesting?/ Source: Created by Araujo (20I2) using the answers from the feedback questionnaire presented at the end of the semester

ISSN: 07 I8-2724. (http://www.jotmi.org)

Journal of Technology Management \& Innovation (c) Universidad Alberto Hurtado, Facultad de Economía y Negocios. 


\section{Final Considerations}

Electronic games are a way of entertainment and interaction very common for children, youth and adults of today, and its use in the teaching and learning process can help in the modernization of it, making it more suited to the Cyberculture, more exciting and interesting for students. Use the learning principles found in good video games is an important way to achieve the desired modernization. The inclusion of games in the routine of the classroom is a challenge, but a necessity that could make the students more committed, interested and active in the learning process.

The games created, deployed and described in this article used simple development techniques, aiming that the creation of them did not require a huge effort to learn new technologies and tools. Templates or off-the-shelf games can also be adopted by teachers, simplifying the development or avoiding it. Even with these cautions in mind it is necessary to emphasize that teachers and professors will only feel confident and willing to include electronic games and even other types of technological resources into their classroom routines, if they are comfortable with the technology they are using. This comfort with the new technologies has been growing since the younger professionals are more used to them, but this is an important point that needs to be assessed in teachers' training and formation.

The observation of the games implementation showed that students were interested in the activities, with a great emotional engagement, not only at the time that they occurred, as throughout the semester, being aware of the dates of the games and talking about them. Although students have seen the introduction of electronic games as a positive practice that can modernize the teaching and learning process, they would still expect that the traditional dynamics of the teacher as transmitter and the student as receiver, happen what may be associated with the fact that the activities were introduced in the context of a traditional class. A radical change of attitude from the part of students or a paradigm shift was not observed, and such changes were not expected, since the introduction of the games was punctual and more associated with content retention than with new content presentation. Students who participated in the activities in the first half of the year were sorry because of the no continuation of the activities in other disciplines when they met the researcher at the premises of the institution.

It is necessary that research on electronic games and the teaching and learning process continues, as the subject addressed here is new and there is still resistance to electronic games in general and its use as a method of teaching and learning. The higher education courses can provide a great opportunity to start this introduction, since it deals with young people who are embedded in the new social dynamics and which are normally open to new experiences and innovations. Additional tests, creating new games and new dynamics can help to make the inclusion of electronic games in daily education a reality, quickly and effectively, bringing benefits to students and professors.

\section{References}

AKKERMAN, S., Admiraal, W., Huizenga, J. (2009). Storification in History Education: A mobile game in and about medieval Amsterdam. Computer \& Education, 52 (2), 449-459

ALVES, L. (2004). Game over: Jogos Eletrônicos e violência. Tese de Doutorado. Universidade Federal da Bahia - UFBA, Bahia.

ARAUJO, C. M. (20I2). Novas Tecnologias em Educação Jogos Eletrônicos e Aprendizagem no Ensino Superior. Centro Federal de Educação Tecnológica Celso Suckow da Fonseca - CEFET/RJ, Rio de Janeiro.

BARBIER, R. (2007). A Pesquisa-Ação. Liber Livro Editora Ltda, Brasília.

BYINGTON, C.A. B. (20I I). Professores no Divã. Revista da ESPM, 18(5), 10- 17

CECCHETTINI, E. (20I I). Introdução. In:VERAS, M (Org.). Inovação e Métodos de Ensino para Nativos Digitais. Editora Atlas, São Paulo. pp. 10-18

COLLIS, J. , HUSSEY, R. (2003). Pesquisa em Administração. Um guia prático para alunos de graduação e pós-graduação. ARTMED Editora, São Paulo.

COSTU, S., Aydin, S., Filiz, M. (2009). Students' conceptions about browser-based learning in mathematics education:TTNetvitamin case. Procedia - Social and Behavioral Sciences, I(I), I848-1852.

DEMIRKBILEK, M., Tamer, S. (20I0). Math teachers' perspectives on using educational computer games in math education. Procedia - Social and Behavioral Sciences, 9. 709-7I6.

ECHEVERRÍA, J. (2004). Los Señores del aire: Telépolis y el Tercer Entorno. Ediciomes Destomp, Espanha.

ECHEVERRÍA, J. (2009). Educación y tecnologias telemáticas. Educación, Ciencia, Tecnología y Sociedad. Documentos de Trabajo n. 3. Centro de Altos Estudios Universitarios de la OEI, Madri. 
GALVIS, M. S. (2010). Implicaciones de Género en la Sociedad de la Información: Un Análisis desde los Determinantes de Uso de Internet en Chile y México. Journal of Technology Management and Innovation, 5(I), 108-I26

GARGALLO-CASTEL, A., Esteban-Salvador, L., Pérez-Sanz, J. (20I0). Impact of Gender in Adopting and Using ICTs in Spain. Journal of Technology Management and Innovation, 5(3), 120-128.

GEE, J. P. (2007). What video games have to teach us about learning and literacy. Palgrave Macmillan, USA.

GRACIOSO, L. (20II). Prefácio. In: VERAS, M (Org.). Inovação e Métodos de Ensino para Nativos Digitais. Editora Atlas, São Paulo. pp. vii-ix

Instituto Nacional de Estudos e Pesquisas Educacionais Anísio Teixeira. http://portal.inep.gov.br/[Accessed December 20II].

LÉVY, P. (1999). Cibercultura. Editora 34 Ltda, São Paulo.

LINDSTRÔM, P., Gulz, A., Haaket, M., Sjödén, B. (20II). Matching and mismatching between the pedagogical design principles of math game and the actual practices of play. Journal of Computer Assisted Learning, 27 (I), PP. 90-102. http://onlinelibrary.wiley.com/doi//0.1/II/j.13652729.2010.00380.x/full. [Accessed Setembro de 20I I].

MATIAS-PEREIRA, J. (2008). Políticas Públicas de Educação no Brasil: A Utilização da EAD como Instrumento de Inclusão Social. Journal of Technology Management and Innovation, 3(I), 44-55.

MATTAR, J. (2009). Games em Educação. Pearson Education, São Paulo.

MEIJ, H.,Albers, E., Leemkuil, H. (20I I) Learning from games: Does collaboration help?.British Journal of Educational Technology, 42(I), 655-664.

PASIN, F. Giroux, H. (20I I). The impact of a simulation game on operations management education". Computer \& Education, 57(I). 1240-1254.

PRENSKY, M. (200I). Digital Natives, Digital Immigrants. On the Horizon. MCB University Press, 9(5).

PRENSKY, M. (2007). Digital Game-Based Learning. Paragon House, St Paul - USA.

PRENSKY, M. (2009). H. Sapiens Digital: From Digital Immigrants and Digital Natives to Digital Wisdom. In- novate. 5(3). http://www.innovateonline.info/index. php?view=article\&id=705. [Accessed September 20I I].

SANTOS, E. O. (2005). Educação online: Cibercultura e pesquisa-formação na prática docente.Tese de Doutorado. Universidade Federal da Bahia - UFBA, Bahia.

TAO, Y., Cheng, C., Sun, S. (2009). What influences college students to continue using business simulation games? The Taiwan experience. Computer \& Education, 53(3), 929-939.

TAPSCOTT, D. (2010).A hora da geração digital. Editora Agir, Rio de Janeiro.

THIOLLENT, M. (1998). Metodologia da Pesquisa-Ação. Cortez Editora, São Paulo.

VYGOTSKY, L. (1988). Aprendizagem e Desenvolvimento Intelectual na Idade Escolar. In: LEONTIEV,A., LURIA,A.VY

GOTSKY, L. Linguagem, desenvolvimento e aprendizagem. Ícone: Editora da Universidade de São Paulo, São Paulo. Pp. $103-117$

VYGOTSKY, L. (1966). Play And Its Role in The Mental Development of The Child.Voprosy psikhplogii. 6. 
J.Technol. Manag. Innov. 2012,Volume 7, Issue 3

ISSN: 07I8-2724. (http://www.jotmi.org)

Journal of Technology Management \& Innovation @ Universidad Alberto Hurtado, Facultad de Economía y Negocios. 